КУЛЬТУРОЛОГИЯ

UDC 1(091)+141.131

\title{
The origins of Platonic pedagogy: an introduction to the study of Minor Plato's dialogues
}

\author{
V. V.Prokopenko \\ V.N. Karazin Kharkiv National University, \\ 6, pl. Svobody, 61022, Kharkiv, Ukraine
}

For citation: Prokopenko V. V. The origins of Platonic pedagogy: an introduction to the study of Minor Plato's dialogues. Vestnik of Saint Petersburg University. Philosophy and Conflict Studies, 2019, vol. 35, issue 3, pp. 497-506. https://doi.org/10.21638/spbu17.2019.309 (In Russian)

The article deals with the question of the ideological content of Plato's "minor" dialogues and their significance for understanding Plato's philosophy. The author sees his goal in showing that the traditionally low assessment of these works by Plato is unfair. Thus, the article provides analysis of the "minor" dialogues in terms of their role in the implementation of Plato's educational strategies. Plato is affirmed never to separate the problems of philosophy and education because philosophy itself was understood by Plato as the education of the soul. The article proposes to consider "Minor Plato's" dialogues as part of the Corpus Platonicum regardless of the solution to chronology and authenticity problems, since these dialogues in one way or another belong to the heritage of the Academy. The article analyzes two dialogues, Clitophon and Theages which are still little studied in Russian literature. The connections between the considered dialogues and the great works of Plato - Republic, Symposium, and Theaetetus are revealed. The author comes to the conclusion that the relationship between these dialogues should be viewed as a "challenge-response" relationship in which the dialogues' back-andforth occurs. It has been established that not only do Plato's major dialogues contain answers to questions posed in Minor Plato's dialogues, but, conversely, Clitophon and Theages become keys to understanding Symposium and Theaetetus. The article proves that Plato made this dialogues back-and-forth in order to achieve better understanding of his philosophical ideas by students.

Keywords: Plato Minor, pedagogic approach, dialogues roll-call, erotosophy.

The starting point of our study is the belief that Plato's philosophy cannot be understood without taking into account his pedagogical activity. We believe that the foundation of the Academy was one of the most important events in Plato's life. In such a way he ex-

(c) Санкт-Петербургский государственный университет, 2019 
pressed his understanding of philosophy as a theory and practice of education. The idea of education occupies an extremely important place in Plato's teachings and, therefore, all his texts are more or less intended to achieve pedagogical goals even those dialogues where completely different questions would seem to be discussed. Such an approach to Plato's philosophy implies reading Plato's dialogues in an educational context. The pedagogical approach appeared in the Platonic studies long ago: in F. Schleiermacher's works at the beginning of the $19^{\text {th }}$ century. Since then the pedagogical hypothesis has never disappeared from the the Platonic studies and experienced a real flourishing in the first half of the $20^{\text {th }}$ century (W. Jaeger, P. Friedlander, J. Stenzel). Subsequently the interest in the image of Plato as an educator was somewhat weakened and gave way to other approaches, in particular, to analytical methodology. Recently, however, we can observe a gradual increase in interest in the educational and institutional aspects of Platonic philosophy in the works of Western and Russian researchers R. Barrow, R. C. Lodge, S. Scolnicov, A. O. Rorty, Yu. A.Shichalin, I. N. Mochalova). We also want to emphasize that Plato devoted most of his life to education: first as a student of Socrates and then as a scholarch of the Academy.

Although very little is known about the pedagogical practices used in the Academy, we have no doubt that the texts of Corpus Platonicum were used as tools in the educational process. And it predetermines the very dialogical form of Plato's works. Therefore, the study must take into account the pragmatic aspect of Plato's dialogues. We believe that in this case it will be effective to apply pragmalinguistic methodology, which assumes that the text is treated as a communicative act. Such a methodology requires taking into account not only the content of the text, but also its form, i.e. the author's rhetoric, poetics and dramaturgy of the work. All these expressive means play a crucial role in transmitting a message from the author to the addressee.

The pragmatic approach allows us to take a fresh look at some of Plato's dialogues, which for a long time have been deprived of the researchers attention and greatly underestimated. They are the dialogues called "small", "early", "Socratic". W. Jaeger, who used the term "Smaller Socratic Dialogues", included "Apology of Socrates", "Euthyphro", "Laches" in this group of dialogues [1, p. 87-160]. But Jaeger does not even mention other small dialogues. W. Guthrie includes nine names in the group, which he called "Early Socratic dialogues". They are "Apology of Socrates" "Crito", "Laches", "Charmides", "Euthyphro", "Lysis", "Hippias Major", "Hippias Minor", "Ion" [2, p.67-324]. G. Vlastos adds "Menexenus" and "Gorgias" to this group, and T. Irwin adds "Protagoras" [3, p. 78-95]. A. F. Losev published "Theages" in the Plato's early dialogues edition in Russian although he expressed doubt about his authenticity [4, p. 66-78]. Losev also included a number of dialogues in this collected works, which he called "the works of the Platonic School" ("Demodocus", "Sisyphus", "Eryxias", "Axiochus"). W. Guthrie considers these dialogues as absolutely unreliable or at least controversial while other researchers (G. Vlastos) do not pay any attention to them at all. M. Canto-Sperber calls these works apocryphal and gives them the following characteristic: "these are plagiarism or essays obviously related to a later time, often consisting of parts borrowed from the real Platonic dialogues. Doubtful dialogues are also excluded ("Hipparchus", "Rival Lovers", "Second Alcibiades", "Minos", "Theages", "Clitophon" and "Epinomis") [5, p.214]. Thus, researchers do not agree the contents of this group of dialogues. Not everyone also agrees that these dialogues should be called Socratic and early. Yu. A. Shichalin subjected the definitions considering these dialogues of Plato as early and insignificant to reasoned criticism [6]. 
Since exact and final context determination of this group of dialogues and their chronology discovering is not the main goal of our research, we will accept the working hypothesis: to separate the Socratic dialogues which are often considered authentic (in accordance with G. Vlastos's list [7, p. 46-47]) and those short dialogues that are almost always considered not genuine. We use the term "Plato's shorter dialogues" here for the name of the second group. This name can be found in some other authors (C.Bruell, C. Warne). Speaking of these dialogues, T.V.Vasilyeva used the expression "The Minor Plato". At the same time she said that today not a single scholar would undertake to draw the line between the Minor and the Major Plato. But this does not mean that the dialogues of the Minor Plato can be neglected. These works have their own value and significance, "for the historian of philosophy this is precious evidence regarding the methods of work in the philosophical schools of the Platonic direction" [8, p. 247]. We admit the correctness of this statement and believe that the study of Corpus Platonicum should include not only the so-called "early", "Socratic" dialogues but also those dialogues that are considered to be the writings of the Platonic school or "Minor" Plato.

According to the tradition of the $19^{\text {th }}$ century these dialogues were not considered of high value. Indeed, in them Plato had not yet shown himself to be a prominent writer and playwright, such as in "Symposium" and "Phaedrus". They do not have sophisticated dialectics, such as in "Parmenides", or in large-scale metaphysical and mythological constructions, as in "Republic" and "Timaeus". But the main reason for neglect of shorter dialogues was precisely the question of their authenticity. Prior to the beginning of the scientific research of Plato, the question of the authenticity of the dialogues was not essential and the authenticity of the dialogue was not a criterion for its evaluation. H. Thesleff noted that "there was no "Plato question" outside the German sphere of influence. Plato and Platonism were interpreted, as a rule, in accordance with the inherited tradition and the issues of dating and little attention was paid to the authenticity of the dialogues" [9, p.3]. The influence of German criticism in classical studies was strong and long lasting. And as a result, the writings of the Minor Plato for a long time remained without a worthy attention to them. The situation began to change only in recent decades due to the proliferation of the dramatic and post-Tubingen approach in Platos research. In the works of Ch. Cahn, M.Erler, T. Slezak, V.Tejera, H. Reid, W. Altmann the Socratic dialogues were largely rehabilitated. Unfortunately, this rehabilitation practically did not touch the dialogues of the Minor Plato.

In our work we will analyze two shorter dialogues by Plato in which, in our opinion, Plato put forward a number of ideas that are fundamentally important for his educational philosophy. In addition, we consider the features of the structure, poetics, rhetoric and drama of these works, which allow us to make conclusions about the place and purpose of Minor Plato's dialogues in Corpus Platonicum.

"Clitophon" is the shortest of Plato's dialogues (406a-410e). Perhaps for this reason, Russian researchers did not pay so much attention to it. We can name only a few pages of the report to this dialogue by V.N. Karpov in his old edition, a short comment by A. F. Losev [4, p. 40; 563-565] and the article by O. Aliyeva where Clitophon is viewed as an example of a Socratic protreptic [10]. Meanwhile, this brief dialogue provoked keen interest in the world science of the XIX - early XX century. The concept of "Kleitophonproblem" appeared at that time. This interest weakened in the postwar years but in recent years several interesting works by G. S. Bowe [11], M. Davis [12], M. Kremer [13], C. Orwin [14] 
have appeared. New translations of the dialogue have been published by C. Orwin and S. Slings [15]. This revival of research interest in Clitophon became particularly noticeable after the publication of the article by D. Roochnic [16]. D. Roochnic relied on C. Orwin's translation and on the work by Johannes Geffken made in 1931, where Roochnic borrowed the title of his article "The Riddle of Cleitophon" (from Geffken - "Das Rätsel des" Kleitophon ").

The "Clitophon" puzzle is, in our opinion, a complex problem. Its first component is the authenticity of the dialogue itself. In ancient times it did not cause doubts and was considered to be absolutely genuine. The most important argument in favor of the authenticity of "Clitophon" is that it was included in the Thrasyllus Platonic Canon (the eighth tetralogy, along with "Republic", "Timaeus", "Critias"). But suddenly in the XIX ${ }^{\text {th }}$ century the situation changed: F. Schleiermacher considered this dialogue not genuine in his reconstruction of the Platonic corps. His main arguments concerned the unaccustomed image of Socrates and the supposedly ideological secondary nature of the dialogue. Since then doubts about the fact that Clitophon was written to Plato became increasingly deep and widespread. At the beginning of the twentieth century A. Taylor confidently stated: "there is no doubt about the non-platonic character of "Clitophon" [17, p. 12]. Supporters of the authenticity of "Clitophon" object to skeptics: "Clitophon" is written from a completely platonic point of view, its author demonstrates a good understanding of Plato's philosophy and a platonic approach to the form of dialogue; the text of "Clitophon" was transmitted along with the Platonic corpus from (at least) the end of the third century B. C. (S. Slings, G. S. Bowe).

Secondly, it is unclear whether "Clitophon" is a complete text. Some scholars believe that "Clitophon" has no independent meaning because it is just a fragment of another large text. We have found such a statement in Losev's comments [4, p. 563]. V.N. Karpov believes that only under this condition "Clitophon" can be considered a genuine work by Plato. Clitophon image also raises some questions. Who is he? Clitophon, the son of Aristonymus, was an Athenian oligarchic statesman and intellectual. According to D. Nails, "Clitophon was a person well-known to Athenians for his flip-flopping political affiliations" [18, p. 102]. Plutarch mentions him in the list of Socrates companions who ultimately rejected the influence of Socrates. Clitophon was an ally of Theramenes, the leader of a moderate oligarchic coup in Athens in 411, and an opponent of the extreme oligarchy of the Thirty. He is also described along with Theramenes in Aristophanes's "Frogs" and Aristotle's "The Constitution of Athens".

That is all we know about historic Clitophon. Why do we need this knowledge? Real Clitophon can not be uniquely identified with the character of Plato. But Plato's prosopography is always well thought out and most of the characters in the dialogues are named after famous people. Plato clearly hoped that his students would use the knowledge of these people for a better understanding of the hidden meaning of the Platonic texts. But often Plato deliberately distorts real characters and circumstances. In the dialogue he presents Clitophon as a sophist. But scant biographical data do not confirm this. Many scholars consider him a disciple and supporter of the sophist Thrasymachus. But there is no evidence that Clitophon was a student of Thrasymachus. And the most important thing is that it is unknown whether Thrasymachus was a sophist himself. Aristophanes, Aristotle and Dionysius of Halicarnassus portray Thrasymachus as a rhetorician and teacher of rhetoric rather than a sophist. 
The third question in the "Clitophon" puzzle concerns the substantive side of the dialogue. The reader does not understand the idea of Plato who represents an entirely unusual Socrates in the dialogue. As a rule, in the dialogues Socrates behaves actively and throws interlocutors with questions, he draws his famous irony on them and puts them in a quandary. In "Clitophon" Socrates faces the same aggressive behavior of Clitophon but does not show any resistance. Clitophon pays tribute to the Socratic upbringing which he presents as a teaching of justice, but then claims that this education is fruitless. "I came to the conclusion that while you're better than anyone at turning a man towards the pursuit of virtue, one of two things must be the case: either this is all you can do, nothing more - as might happen with any other skill, for example, when someone who's not a pilot rehearses a speech in praise of the pilot's skill as being something of great worth to men; the same could also be done for any other skill. And someone might accuse you of being in the same position with justice, that your ability to praise it so well does not make you any more knowledgeable about it. Now that's not my own view, but there are only two possibilities: either you don't know it, or you don't wish to share it with me" [19, p.970]. Having said that, Clitophon goes to Thrasymachus. Socrates is silent and Plato does not explain his silence. A. F. Losev interprets Socrates' silence as the correct response to Clitophon irritation by Socratic maeutics. Socrates-maeuticus makes the student seek wisdom on his own, which angered Clitophon. Being silent Socrates refuses to be Clitophon's teacher. We believe that this is not the case. Socrates does not give up the role of a teacher, he simply does not agree with the fact that knowledge can be transferred directly without observing special conditions. Plato says this in "Symposium": "It would be a happy state of affairs, Agathon, if wisdom were something that could flow between us through mere contact, from the one who is full to one who is empty, like water flowing along a strand of wool from a full cup to an empty one" [20, p.5]. Clitophon is not yet ready to accept the conditions which require independent spiritual work from him.

A sudden end of the dialogue leaves the reader perplexed; he believes that the dialogue is not over yet, since Plato has not finished talking about justice. In this regard, "Clitophon" is not unique; most of Plato's small dialogues interrupt so unexpectedly too. Plato needs an open-ended dialogue in order to stimulate the students' own cognitive efforts though he has other tasks. Dialogues roll-call is a didactic technique which is often used by Plato. In small dialogues Plato poses questions, the answers to which he places in very different places. And we should agree that in order to find the solution for the "Clitophon" one should turn to "Republic".This dialogue is much more than any other suitable for the role of a kind of metatext which explains the meaning of "Clitophon". Clitophon reappears in the first book of the "Republic". He is not particularly active in this dialogue but his very presence makes us recall the dialogue of the same name. Clitophon defends Thrasymachus's theory of justice; therefore Socrates' critique of this theory is also directed at Clitophon. The silence of Socrates in the dialogue "Clitophon" was interrupted in the "Republic". Socrates answers are not definitive but they contribute to the discussion of the problem of justice at a higher level. In the end, this discussion covers all major areas of philosophical knowledge. It explains why Thrasyllus has given the dialogue "Republic" the subtitle "On Justice". We believe that the common interpretation of "Clitophon" as a lost component of the "Republic" is not at all true. The relationship between these dialogues can rather be described by the terms "chal- 
lenge" and "response". Between challenge and response (which is never definitive), Plato leaves room for the independent cognitive activity of the students. In accordance with the principles of Socratic maeutics, Plato asks leading questions to the students, he gives hints and tips.

Let us test our hypotheses on the material of another short dialogue called "Theages". The choice of this dialogue is logical because of its obvious pedagogical orientation. In it Plato poses the very first and most important questions about education: what should a pupil learn, from whom should he learn and what will he achieve as a result? Unlike other dialogues education in "Theages" is the main and the only topic. The research of "Theages" is very similar to that of "Clitophon". This dialogue is also not particularly popular with researchers who suspect it of being unauthentic. In ancient times "Theages", as well as "Clitophon", was considered an authentic work of Plato. Diogenes Laërtius mentions it among Plato's works, Thrasyllus includes him in the fifth tetralogy of Plato's works, Aristophanes of Byzantium also considered "Theages" the work of Plato. Doubts about the authenticity of this dialogue appeared later, at the beginning of the $19^{\text {th }}$ century. At the beginning of the twentieth century J. Burnet directly calls this dialogue "pseudoplatonic" [21, p. 130]. Nevertheless, there were supporters of the authenticity of "Theages", among whom such prominent scientists G. Grote and P. Friedlander should be mentioned. V.S. Soloviev presented a convincing system of arguments in favor of the authenticity of this dialogue [22]. M. Joyal, the author of the new "Theages" commented translation, analyzed the arguments of both sides. As a result, M. Joyal concluded that the dialogue was authentic. In his opinion, in the early Academy there simply were no philosophers other than Plato who could independently create works of a similar level. Today's article commentary by M. Joyal alomg with the work of T. Pangle [23] and S. Benardete [24] is the most detailed study of "Theages".

We suppose that the question of whether it was Plato who was the author of this dialogue should not affect the assessment of "Theages". Even if its author was not Plato himself, then, most likely, it was one of his students. In any case, the academic background of "Theages" is beyond doubt. Combining several topics that occupy an important place in the educational strategy of Plato, "Theages" is of particular interest for our study. First of all, we see that pedagogical issues are exclusively considered in the dialogue, and there are no usual Plato's deviations. The word "philosophy" in "Theages" is never pronounced, however, in the canon of Thrasyllus the dialogue is accompanied by the subtitle "On Philosophy". This title correctly indicates the Platonic idea of the unity of education and philosophy, clearly expressed in "Theages". For Plato philosophy is not the body of knowledge that is transmitted in the process of education. But philosophical wisdom also does not grow by itself in the human soul. Philosophy is education ( $\pi \alpha i \delta \varepsilon i \alpha)$ and this education is

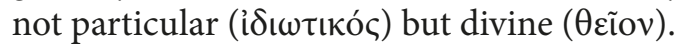

Therefore, the divine topic appearance in the dialogue should be considered natural. It is about daimonion (Saıjóvıv) of Socrates. The conversation about daimonion begins in the dialogue without any preliminary clarification, just like in "Apology" or "Euthydemus". This indicates that the listeners of Plato were already familiar with this mysterious phenomenon. There is an opinion that Plato expounded the teachings of Socrates and not his own ones in his early dialogues. The proponents of this interpretation believe that Plato fully borrowed the topic of the divine voice ( $\varphi \omega v \eta$ ) from Socrates. But the evidence of contemporaries suggests that Socrates himself was most likely poorly aware that this was a voice giving him signs. 
Having received no explanations from the teacher, the students of Socrates interpreted this mysterious power as a simple and habitual ability of divination and prediction. For instance, Xenophon wrote about this: "To begin with, then, what possible evidence did they use to show that he did not believe in the gods in which the city believed? For he visibly sacrificed often at home and often at the common altars of the city; and it was not difficult to see him using divination. For it had been widely bandied about that Socrates said that the divine thing (to daimonion) gave him signs; and, in my opinion it is especially for this reason that they accused him of bringing in new divine things (daimonia)" $[25$, p. 1]. In the Greek folk religion the concept of daimons was also extremely vague. Daimon $(\Delta \alpha i \mu \omega v)$ was considered to be a deity of a lower order, something average between gods and heroes. Daimons often personified a force hostile to man, they deprived a person of independence subordinating him. There was neither cult nor images of these semi-divine beings.

Taking into account these circumstances, Plato should be recognized as the only true creator of philosophical "demonology". He only outlines the ways of this concept development in "Theages" and considers it in a pedagogical context from the very beginning. This is confirmed by the "Theages" composition in which the daimonion message appears only in the last quarter of the dialogue. If we assume that "Theages" is just a naive attempt to understand the daimonical phenomenon of Socrates (A. A. Taho-Godi), then most of this dialogue will have to be viewed as a too lengthy introduction. On the contrary, we believe that the first part of "Theages" is of great importance. Here Plato asks questions about the essence of learning, about the necessary qualities of a student and teacher. And he shows that all attempts to find answers to these questions lead to insurmountable difficulties (àropía).

A message about the mysterious science of love ( $\mu \dot{\alpha} \theta \eta \mu \alpha \dot{\varepsilon} \rho \omega \tau$ เóc): "I know none of these magnificent and splendid subjects. I wish I did! I am always saying, indeed, that I know virtually nothing, except a certain small subject - love, although on this subject, I'm thought to be amazing, better than anyone else, past or present" $[26,635]$ appears in the dialogue to overcome these aporiai of education This remark of Socrates remained misunderstood by his interlocutors. As T. Pangle notes, they considered this dark statement of Socrates to be just a joke: “To Theages, however, Socates' extraordinary, if obscure, declaration of his erotic knowledge is a totally incomprehensible sort of 'jesting. It explains and justifies nothing; it does not even provoke questions or thought. It simply conveys Socrates' stubborn and unreasonable refusal to help Theages" [23, p. 130]. This stylistic device is characteristic of all the Platonic dramaturgy: Plato often makes his characters not to understand and ignore the most important words, he puts these words in the background and this distracts the attention of the uninitiated reader from them. Why does he do that? Our answer is like this: to teach the student how to see the hidden meaning of what was said and master the art, which L. Strauss called "reading between the lines".

Plato does not give ready-made answers but he leaves hidden instructions on how to solve problems in the dialogue. These instructions are for students who are on a strictly defined level of development. In accordance with the theory of knowledge given at the end of the sixth book of "Republic", it is impossible to rise right up to the highest area of knowledge. No one will reach intelligible ideas without going through the lower stages first. Cognition begins with "shadows" and "reflections" perceived by means of assimi- 


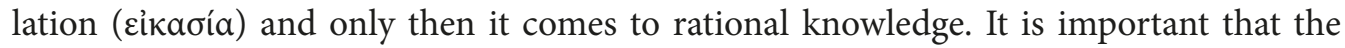
student must follow this path on his own under the guidance of a teacher. To gain higher wisdom one faces the question of the energy required for this movement and the direction of this movement. Thus, the interlocutors could not explain the need to learn wisdom in the first part of "Theages". Young Theages has only an inexplicable passion for wisdom. When Socrates speaks of the science of love, he shows the young man the force that leads a person to the truth. The same instruction is given to the reader through the creation of a situation of misunderstanding, not directly. Misunderstanding, in its turn, leads to surprise and surprise is the beginning of philosophy according to Plato.

Speaking about the "science of love", Plato does not clarify what kind of science it is and how it relates to Eros. It is possible that the students of Plato, to whom the dialogue was addressed, already knew where to look for answers to these questions. When Socrates promises the young man to explain everything, he begins to tell him about his daimonion, which, at first glance, has no direct relation to the mysterious "science of love". The gap between the question and the answer is so wide that it divides the dialogue into two parts as if they belong to two different authors. Such lacunae and dramatic narrative move are found in other dialogues of Plato. They almost always indicate that the answer to the question must be sought outside the dialogue. And such a search with respect to $\mu \dot{\alpha} \theta \eta \mu \alpha$ $\dot{\varepsilon} \rho \omega \tau \iota k o ́ \varsigma$ leads us to the "Symposium" dialogue in which Socrates speaks of the science of love again: "I would hardly say no, since the only subject I can claim to know about is love" [20, p. 8]. It is in "Symposium" that Plato develops his erotosophy in which it is necessary to look for answers to the questions posed in "Theages". Here it becomes clear that Eros and the daimonion of "Theages" are one and the same supernatural being that serves as an intermediary between wise gods and ignorant people. What reasons make us think so? Speaking about Eros in Symposium, Plato constantly emphasizes the dual nature of this god. Due to this duality Eros plays the role of mediator between wise gods and ignorant

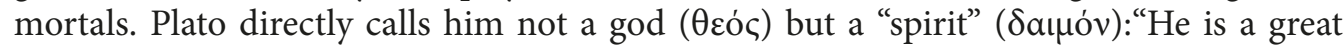
spirit, Socrates. All spirits are intermediate between god and mortal $\langle\ldots\rangle$ These spirits are many and of many kinds, and one of them is Love" [20, p. 39]. It is likely that the anonymous god, which Plato speaks of in Theaetetus as the culprit of the birth of knowledge, is the same Eros-daimonion.

Thus, we come to the conclusion that Minor Plato's dialogues owe their brevity and fragmentation not to the youth and inexperience of their author. It is unlikely that they can also be considered fakes. We see that the specific features of "Clitophon" and "Theages" are due to the role that Plato assigned them in his pedagogical strategy. First of all, they are aporetic dialogues. But not only difficulties are formulated here. These dialogues play the role of guides. Thus, the problems formulated in "Clitophon" find their solution in the "Republic". The questions posed in "Theages" become clear when reading "Symposium" and "Theaetetus". Because of this Minor dialogues in the corpus of Plato's writings should be read by students before the dialogues of the Major Plato.

But on the other hand, "Clitophon" explains the reasons for addressing the topic of justice in the Republic. "Theages", in its turn, is the key to understanding the teaching of Eros in "Symposium". The key word here is understanding, which Plato the teacher cares about. To help the students understand and assimilate the ideas of Plato, he organizes such a dialogues roll call. If it were not for this concern, the philosopher could have chosen a much simpler narrative form of presentation of his philosophy. 


\section{References}

1. Jaeger, W. (1947), Paideia: The Ideals of Greek Culture, vol. 2, Basil Blackwell, Oxford, 461 p.

2. Guthrie, W. K. C. (1975), A History of Greek Philosophy, in 6 vols, vol. 4, Cambridge University Press, Cambridge, $624 \mathrm{p}$.

3. Irwin, T. (1995), Plato 's Ethics, Oxford University Press, Oxford, 464 p.

4. Plato (1986), Dialogi [Dialogues], ed. by Losev, A. F., Mysl' Publ., Moscow, 607 p. (In Russian)

5. Kanto-Sperber, M. (2006), Plato, in Grecheskaya filosofiya, vol. 1, Greko-latinskii kabinet Yu. A. Shichalina Publ., Moscow, pp. 204-332. (In Russian)

6. Shichalin, Yu. A. (2015), Plato: from Socrates to the presocratics?, Vestnik Pravoslavnogo Sviato-Tikhonovskogo gumanitarnogo universiteta. Ser. I: Theology. Philosophy. Religious Studies, vol. 2, no. 58, pp. $27-$ 42. (In Russian)

7. Vlastos, G. (1991), Socrates: Ironist and Moral Philosopher, Cambridge University Press, Cambridge, $334 \mathrm{p}$.

8. Vasil'eva, T. V. (2008), The Way to Plato, in Vasil'eva, T. V., Poetika antichnoy filosofii, Akademicheskii proekt Publ.; Triksta Publ., Moscow, pp. 217-397. (In Russian)

9. Thesleff, H. (1982), Studies in Platonic Chronology, Societas Scientiarum Fennica, Helsink, 283 p.

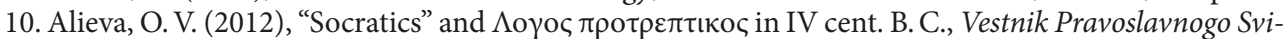
ato-Tikhonovskogo gumanitarnogo universiteta. Ser. I: Theology. Philosophy. Religious Studies, vol. 3, no. 41, pp. 105-114. (In Russian)

11. Bowe, G. S. (2007), In Defense of Clitophon, Classical Philology, vol. 102, no. 3, pp. 245-264.

12. Davis, M. (1998), On the Intention of Plato's Clitophon, Mètis: Anthropologie Des Mondes Grecs Anciens, vol. 13, no. 1, pp. 271-285.

13. Kremer, M. (2004), Plato's Cleitophon: On Socrates and the Modern Mind, Lexington Books, Lanham, $\mathrm{MD}, 100 \mathrm{p}$.

14. Orwin, C. (1987), On Cleitophont, in Pangle, T. (ed) The Roots of Political Philosophy. Ten Forgotten Socratic Dialogues, transl, with interpretive essays, Cornell University Press, Ithaca and London, NY, pp. 111-131.

15. Slings, S. R. (ed.) (2004), Plato: Clitophon, Cambridge University Press, Cambridge, 380 p.

16. Roochnik, D. L. (1984), The Riddle of Cleitophon, Ancient Philosophy, vol. 4, no. 2, pp. 132-145.

17. Taylor, A.E. (1926), Plato. The Man and His Work, Methuen \& Co LTD., London, 536 p.

18. Nails, D. (2002), The people of Plato: a prosopography of Plato and other Socratics, Hackett Publishing Company, Indianapolis, $464 \mathrm{p}$.

19. Plato (1997), Clitophon, in Cooper, J. M. and Huthinson, D. S. (eds), Plato. Complete works, Hackett Publishing Company, Indianapolis, pp. 965-971.

20. Plato (2008), The Symposium, Howatson, M.C. and Sheffield, F.C.C. (eds), transl. by Howatson, M. C., Cambridge University Press, Cambridge, 128 p.

21. Burnet, J. (1950), Greek Philosophy. Thales to Plato, Macmillan and Co. Ltd, London, 360 p.

22. Solov'ev, V.S. (1899), Reasoning on Theages, in Tvoreniia Platona, vol. 1, K. T. Soldatenkov Publ., Moscow, pp. 47-62. (In Russian)

23. Pangle, T. (1987), On the Theages, in Pangle, T. (ed.), The Roots of Political Philosophy. Ten Forgotten Socratic Dialogues, Cornell University Press, Ithaca and London, NY, pp. 147-175.

24. Benardete, S. (1953), The Daimonion of Socrates: A Study of Plato's Theages: a dissertation submitted to the faculty of the division of the social sciences in candidacy for the degree of master of arts, Chicago University, Chicago, IL, $44 \mathrm{p}$.

25. Xenophon, Memorabilia (1994), transl. by Bonnette, A. L., Cornell University Press, Ithaca and London, NY, $171 \mathrm{p}$.

26. Plato (1997), “Theages", in Cooper J.M. and Huthinson D. S. (eds), Plato. Complete works, Hackett Publishing Company, Indianapolis, pp. 627-639.

Received: February 9, 2019

Accepted; June 13, 2019

Author's information:

Vladimir V.Prokopenko - Dr. Sci. in Philosophy, Professor; PVlad99@gmail.com 


\section{Истоки платоновской педагогики:}

\section{введение в исследование диалогов малого Платона}

\section{В. В. Прокопенко}

Харьковский национальный университет им. В.Н. Каразина, Украина, 61022, Харьков, пл. Свободы, 6

Для цитирования: Prokopenko V. V. The origins of Platonic pedagogy: an introduction to the study of Minor Plato's dialogues // Вестник Санкт-Петербургского университета. Философия и конфликтология. 2019. Т. 35. Вып. 3. С. 497-506. https://doi.org/10.21638/spbu17.2019.309

Среди платоновских сочинений выделяется группа диалогов, отличающихся малым объемом и бедностью содержания. Часто их считают или незрелыми опытами юного сократика Платона, или сочинениями учеников самого Платона. Большая часть их признается сегодня неподлинными. Традиционно эти диалоги оцениваются невысоко. В статье ставится задача пересмотреть отношение к диалогам «малого Платона», обладающим собственной ценностью, которая раскрывается при рассмотрении их в контексте педагогических стратегий Платона. Вопрос об аутентичности этих диалогов автор считает для их оценки несущественным, придерживаясь гипотезы о коллективном авторстве сочинений Платона, созданных в Академии. Также исключается и вопрос о хронологии: важен порядок чтения диалогов, а не порядок их создания. Платон, как утверждается в статье, никогда не разделял проблемы философии и образования, и сама философия понималась им как деятельность по воспитанию души. Диалоги созданы для достижения воспитательных целей, которые ставятся Платоном перед учениками, которым диалог адресован, и зависят от уровня их развития . В статье рассматриваются два малоисследованных в отечественной литературе диалога: «Клитофон» и «Феаг». Особое внимание уделено структуре, драматургии и риторике диалогов, поскольку именно в них воплощены дидактические замыслы Платона. Установлено, что эти диалоги посвящены проблемам воспитания мудрости и представляют собой апоретические введения к диалогам «Пир», «Теэтет», «Государство», в которых эти апории получают свое разрешение: в частности, так создается Платонова эротософия. Автор предлагает рассматривать отношения между этими диалогами как вызов и ответ. Платон устраивает перекличку диалогов: «большие диалоги» решают проблемы, поставленные в «малых», но и «Клитофон», и «Феаг» также важны для понимания «Пира», «Теэтета», «Государства», по отношению к которым они выполняют функцию своеобразного кода доступа.

Ключевые слова: малый Платон, педагогический подход, диалог диалогов, эротософия.

Статья поступила в редакцию 9 февраля 2019 г.; рекомендована в печать 13 июня 2019 г.

Контактная информация :

Прокопенко Владимир Владимирович — д-р филос. наук, проф.; PVlad99@gmail.com 